\title{
The political importance of energy cooperation between Germany and Denmark on the European Union energy market
}

\author{
Mariusz Ruszel ${ }^{1}$ \\ ${ }^{1}$ Department of Economics, Faculty of Management, Rzeszow University of Technology, al. Powstancow Warszawy 8 street, 35-959 \\ Rzeszow, Poland
}

Keywords: Germany, Denmark, EU internal energy market, interconnector, renewables

\begin{abstract}
Denmark and Germany have similar goals of energy transition. Both states are going to implement a policy that is aimed at the transition from a fossil fuel-based system towards a renewable energy system with variable renewables generation. The main objective of the German energy transition is to cover more than $80 \%$ of the energy consumption with renewables by 2050. For comparison, Denmark is going to build a fossil fuel-free system, which would be able to cover $100 \%$ of energy consumption with renewables by 2050 . To this end, stronger cooperation between Germany and Denmark could enhance the position of both countries on the EU energy market. The main aim of this paper is to analyse the impact of the energy cooperation between Germany and Denmark. It is crucial to answer the question of how both states could build a stronger energy position and which tools would be useful in this regard. Denmark is the world's leader in the deployment of wind power, which is also implemented in the northern part of Germany. For this reason, both states have similar challenges with respect to the stabilisation of electricity systems. The current and prospective integration of energy systems of both countries is also important for the improvement of energy security. It is also crucial to answer the questions whether the energy integration will have political implications for both countries, and whether stronger energy cooperation between Germany and Denmark will strengthen the competitive advantage of German economy in the EU.
\end{abstract}

\section{Introduction}

Denmark and Germany are two neighbouring countries with similar long-term goals of energy policies. Both countries have decided to carry out energy transition understood as gradual replacement of fossil fuels with renewable energy sources. Denmark currently has one of the most innovative energy policies worldwide. In the mid-1970s (after the 1973 oil crisis), a decision was made to develop cogeneration and extend the potential of renewable energy sources (RES), improve energy efficiency and develop dispersed generation [1]. In Germany the interest in the issue of renewable energy sources grew after the 1973 oil crisis [10]. Both countries strive to enhance their energy self-sufficiency and to reduce the dependence on imported energy raw materials, such as crude oil and natural gas. Denmark and Germany have social support for the implementation of energy policies resulting in high prices of energy for the community. Having similar objectives connected with energy transition also means that they have common challenges and goals. Therefore, the question arises of whether their mutual political cooperation will contribute to higher positions of these countries on the common EU energy market. How much will the existing and prospective natural gas and electricity interconnections help achieve flexible exchange and balance of the grids? This is especially important in the context of high participation of unstable renewable energy sources in energy balances of those countries. Another question is what will be the role of Norway in the integration of energy systems of Denmark and Germany. Are Denmark and Germany going to become electricity distribution centres in the EU?

\section{Selected challenges}

Energy transition in Denmark and Germany is associated with similar political and economic challenges for the countries. First, both of them are extensively developing wind energy systems, which need to be properly integrated with the electric system. This energy source is dependent on changeable atmospheric conditions, namely, wind speed. That is why the challenge is to stabilise the power grids with which wind power plants are integrated. In Denmark, these power plants satisfy nearly $40 \%$ of electricity demand (2014), and by 2020 their participation is to grow up to $50 \%$ [2]. The challenge faced by Denmark and Germany is to ensure the proper amount of energy in the system whenever the energy production is very high or whenever energy is not produced because of lack of wind [3]. Therefore, it is necessary to balance energy production in unstable weather conditions. Moreover, not all the elements of power transmission system in Germany and Denmark have enough capacity. This is especially noticeable in Germany, where it is necessary to further extend power transmission lines with energy storage projects [4]. Technical limitations caused by insufficient capacity of transmission networks lead to disturbances on the energy market and "loop flows", which upset Polish, Czech, and even Austrian power systems. A very important challenge is to improve the effectiveness of forecasting electric energy demand in certain regions of Germany and Denmark. Along with the increase of effectiveness of these activities, the risk of ordering the wrong amount of balance energy will decrease.

In Denmark and Germany, different measures to improve the flexibility of the power system are being considered. The effective use of electricity

\footnotetext{
${ }^{a}$ Corresponding author: Mariusz Ruszel PhD, mruszel@prz.edu.pl
} 
interconnections is perceived to have huge potential. Investments are being realized that involve increasing the flexibility of production capacity, as well as systems designed to use electrical energy for the production of thermal energy. Introducing new services to the market and better management of supply and demand by means of implementation of intelligent grids is also discussed [5].

A significant political challenge is the growing price of electricity for citizens. It has made the social support for energy transition in Germany and Denmark slightly decrease in the 2013-2015 period. A study carried out by TNS market research company for the German Industrial Mining, Chemistry and Energy Union shows that in $2015,57 \%$ of German citizens evaluated the decision on energy transition as good or very good. [6]. This is a drop by $11 \%$ in comparison with the year 2013 [6]. The situation is the result of growing prices of electricity for the citizens of the two countries. A significant political instrument preventing the social support for energy transition from decreasing even more quickly is the participation of both countries' local communities in RES sector investments, which makes the investing part of the community also benefit from it financially. However, whereas in Denmark energy production is one of the cheapest in Europe, ecotaxes imposed on the energy meant that the Danes paid the highest price for electricity in 2015. The situation is similar in Germany, where citizens also pay one of the highest prices for electrical energy. It is estimated that the total extra payments for renewable energy in an electricity bill of a German citizen are already more than double the price of electricity on the energy market [6]. In the past, it seemed that the German and Danish societies could afford it, since the share of energy costs in household expenses is $4-5 \%$. The costs of electricity are particularly high for the people living in Denmark [7]. Research carried out in the Danish community showed that the Danish people identify with the energy policy of their country that aims at increasing energy selfsufficiency, the development of renewable energy sources, and the development of new technologies in the field of energy [7]. A study carried out by B.K. Sovocool and P. L. Blyth confirms that the Danish people perceive the technological development as the main solution to the problems related to energy [7]. At the same time, it is evident that the Danes' attitude and understanding of the goals of their country's energy policy is influenced by their education in the area of energy [8]. However, the current European challenges make particular communities expect lower electricity prices. In May 2016, the Danish government decided that the extra payment for green energy in electricity bills, amounting to $11 \%$, would be abolished by the end of 2016 [9]. In June 2016, the Danish government made a political decision to withhold the work on wind power plants that were to be located along the coastline [11].

Comparing the two countries, it must be noted that both of them have very well developed energy infrastructure. Germany has a varied energy mixture thanks to carbon, gas, nuclear and renewable power plants. Proper use of the infrastructural potential makes it easier to achieve the goals connected with energy transition. In Denmark, ongoing development of dispersed generation is important. Denmark has decentralised its electrical energy system, developing small generations all over the country. Both countries also benefit from the export of technologies connected with renewable energy sources. The key role in RES promotion is not only played by the energy and climatic policy of the EU, but also by the International Renewable Energy Agency (IRENA), established at the crossgovernmental conference in Bonn in 2009. IRENA facilitates the promotion of international use of RES and green technologies.

\section{Political and economic benefits from the cooperation}

Political and economic cooperation in the field of energy between Denmark and Germany gives mutual benefits in terms of energy security of both sides.

First of all, it strengthens the security of natural gas supplies. Denmark and Germany have the Ellund interconnector, which ensures transfer from Germany to Denmark of 2.26 billion m3/year, and from Denmark to Germany of 1.22 billion m3/year. Currently, this twoway connection is used to receive natural gas contracted by the DONG Energy concern (Denmark) from the Gazprom concern (Russia), supplied via the Nord Stream pipeline. Under the signed contracts, DONG Energy receives $2 \mathrm{bcm}$ natural gas a year, and the German transmission system serves the transit function as part of performance of this gas contract. It must be pointed out that this connection can also be used to transfer natural gas to Germany.

Second, mutual electricity interconnections improve the flexibility of the electrical energy system and facilitate the commercial exchange of power in the case of market surpluses. Denmark and Germany have an electricity connection Kontek with the power of 600 MW, and another AC network with the power of 1,500 MW is planned. Furthermore, both countries are currently extending electricity interconnections with Norway, which has well developed water energy based on pumped storage power plants, which can be used to store electrical energy. Denmark already has electricity interconnectors with Norway: Skagerrak 1/2 - 500 MW, Skagerrak 3 - $500 \mathrm{MW}$, and Skagerrak 4-700 MW [14]. As for Germany, it is planning to build a 1,400 MW electricity interconnector Nord-Link, which is to be completed by 2020 . It will be an undersea $380 \mathrm{kV}$ direct current cable with the length of $623 \mathrm{~km}$, connecting Tonstad in Norway with Wilster in Germany. It must be underscored that Germany has extended the production capacity of renewable energy in the north part of the country, but has not managed to construct relevant transmission infrastructure to connect the northern part of the country with the southern part. Therefore, Germany has limited possibilities to send power and needs to send electric power to the south through the Polish transmission system, causing so-called loop flows. This leads to significant disturbances 
of the electrical energy system in the neighbouring countries, e.g. in Poland and the Czech Republic. It seems that integrating the electrical energy systems of Norway, Denmark and Germany will contribute to the development of flexible exchange of electricity between these countries. Flow directions may differ in the case of small or large amount of energy produced by wind power plants. Moreover, it will help meet the assumed goals of energy transition in Denmark and Germany. It will also strengthen emergency response mechanisms. Besides, it will provide the basis for better use of Norwegian energy potential based on water power plants. Norway may become the EU "green storage". Integrating electrical energy systems and flexible exchange is an option to choose instead of extension of electrical energy storages or creating excessive power reserves in Germany. Especially that unstable wind energy requires power protection in order to stabilize the grid. It is also worth pointing out that further development of HVDC (high-voltage direct current) connections is planned between Denmark and: the Netherlands (COBRAcable - 700 MW by the year 2018), Great Britain (DK1-United Kingdom - 700 MW/1400 MW by 2020) and Germany (DK-1 - 3,500 MW by 2022 as well as Kriegers Flak - 400 MW by 2019) [12].

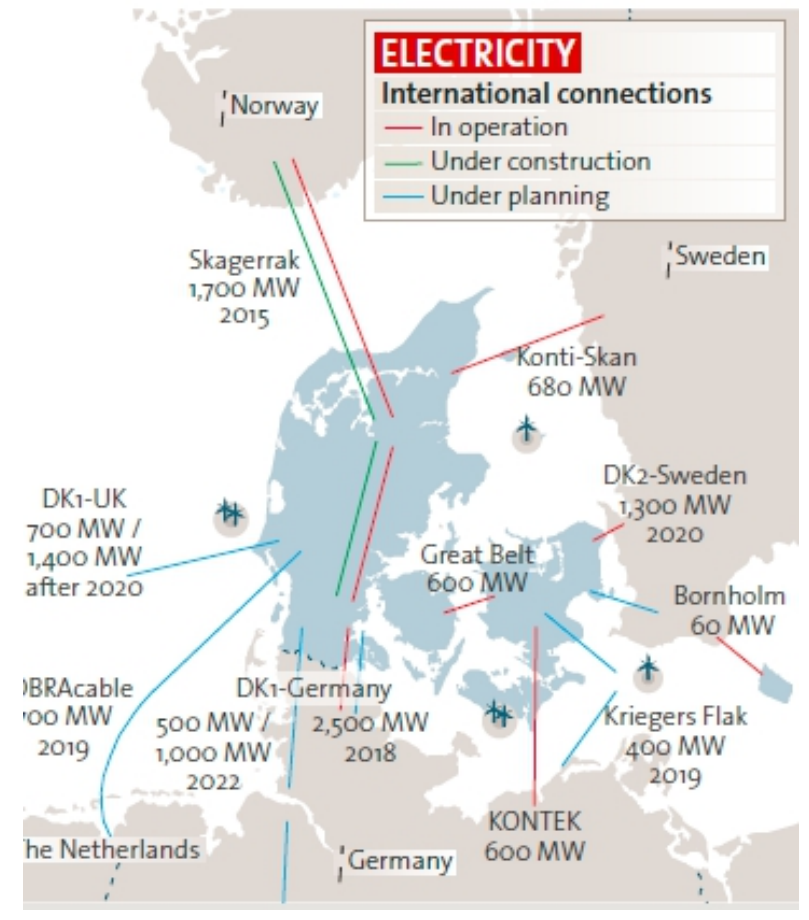

Figure 1. Electricity connections between Denmark and Germany - 2015 [12].

Third, electrical energy integration of Denmark and Germany will help strengthen the economic position on the common energy market and the political position in the EU. Comparing wholesale prices of electricity in EU countries, it is evident that in Denmark and Germany electricity is cheaper than in other member states. This results from the following factors: Surpluses of electricity produced by wind power plants in the northern part of Germany lead to the phenomenon of negative electricity prices, which affect electricity prices on the German stock exchange. This way, the price of electricity exported from Germany can be lower than the prices of electricity in the neighbouring countries. In the years 2014-2015, all the EU neighbours of Denmark and Germany had higher wholesale prices of electricity. Only in 2015, the wholesale price of electricity was the same in Germany and in Austria, whose electrical energy system is integrated with the German one. This results in increasing the possibility of exporting Danish, German and even Norwegian electricity. In the context of integration of common energy market in the EU and extension of capacity of electricity connections, the proper energy infrastructure will be developed to make it easier for the countries producing cheapest electrical energy to use their comparative advantage. It should be remembered that electricity bills for German or Danish citizens are higher than for industrial customers. Consequently, the retail prices of electricity in those countries are among the highest in the EU. This increases the competitiveness, not only of the energy sectors in Denmark and Germany, but also of the fields of industry that are dependent on electrical energy. This way, economic development is promoted in those countries, which leads to new workplaces. This mechanism can only work well if there is social approval for the fact that the price of electricity for German or Danish citizens is higher than for industrial customers. This way, production companies get discounts.

Fourth, electrical energy integration between Denmark, Germany and Norway is part of the European plans of establishing a common energy market. In 2006, the European Regulators' Group for Electricity and Gas (ERGEG) presented the Electricity Regional Initiative (ERI), including seven regional electrical energy markets in Europe: Baltic, Central-East, Central-South, CentralWest, Northern, South-West, France-UK-Ireland [13]. It must be pointed out that Germany is the only country that belongs to four regions: Central-East (Austria, Czech Republic, Germany, Hungary, Poland, Slovakia, Slovenia), Central-South (Austria, France, Germany, Greece, Italy, Slovenia), Central-West (Belgium, France, Germany, Luxembourg, Netherlands), Northern (Denmark, Finland, Germany, Norway, Poland, Sweden) [13]. On the one hand, geographical conditions, i.e. Germany being located centrally in Europe, gives it the potential of becoming the electricity distribution centre. On the other hand, it is worth stressing that in all the four regions that Germany is in, wholesale prices of electricity are lowest in three countries: Norway, Denmark, and Germany. This means that developing the project of a common European energy market by developing regional markets and enhancing the capacity of interconnections and stock exchange instruments will provide the right conditions for the export of electricity produced in Norway, Denmark and Germany to the other European countries. Germany will serve a unique role in this process, as it can become a transit country for Norwegian and Danish electrical energy. 


\section{Summary}

In the 1970s, Denmark and Germany decided to increase their energy self-sufficiency and decrease the dependence on imported fuels, i.e. crude oil and natural gas. These decisions have resulted in energy transition, currently being realized in both countries. Denmark and Germany have similar goals regarding energy transition, which is going to increase the use of renewable energy at the expense of conventional energy in the future. In order to meet these goals, they have to face challenges of integrating renewable energy with their national electrical systems. Among many possible options, it seems most prospective to integrate the energy industry with the heat industry to a greater extent. This will ensure better use of energy surpluses, lower energy losses and facilitate energy storage, since heat energy storage facilities are more efficient. A huge political challenge is the growing price of electricity for citizens, which in 2016 caused some adjustments in political decisions as a result of poor social support for energy transition. The model of transition adopted by Denmark and Germany requires appropriate expenditure, as by assumption it is to support the competitiveness of industries in these countries and become the instrument to achieve the goals of the economic dimension of foreign policy. Political cooperation between the countries strengthens their energy security, improves the flexibility of the energy system, facilitates the export of electricity, fits the European plans of establishing a common electricity market, and enhances their competitive advantage on the integrating market. Gradual development of regional markets - and ultimately, a common EU energy market - is going to increase competition between electricity producers. At the moment, Denmark and Germany have one of the lowest wholesale prices of electrical energy. Taking into account the plans of enhancing the integration of systems in these countries and the connections with Norway, where the water energy potential is huge, Denmark and Germany may definitely play the crucial role on the common energy market of the EU. They have all the instruments necessary to become electricity distribution centres, which will translate into economic development and more workplaces.

\section{References}

1. F. Hvelplund, Environ. Res. Eng. Manag., 66/4 (2014). 2. A. Estermann, Interconnection and cross-border market integration, Perspective of 50Hertz, Berlin 24.09.2015.

3. A. Kofoed-Wiufd, The Danish Experience with Integration of Variable Renewable Energy, Ea Energy Analyses, Berlin 24.09.2015.

4. M. Stark, System and Market Integration - The Perspective of a German Energy Trader, Berlin 24.09.2015.

5. T. Olkuski, E. Ciesielka, A. Szurlej, Rynek Energii, 2 (2015).

6. Niemcy płacą za OZE więcej, niż za samą energię [Germany pays for RES more than for energy itself], http://wysokienapiecie.pl/oze/1302-cena-energii- elektrycznej-polsce-2015-niemczech 10.06.2016].

[access:

7. B. K. Sovacool, P. L. Blyth, Environ. Sci. Policy, 54 (2015), pp. 304-315.

8. B. K. Sovacool, Soc. Stud. Sci. 40 (2010), pp. 1147 1157.

9. M. Druś, Duńczycy nie będa doptacać do ,zielonej" energii [Danes are not going to pay extra for "green energy"], http://www.pb.pl/4432983,32820,dunczycy-niebeda-doplacac-do-zielonej-energii [access: 10.06.2016]. 10. B. Morris, M. Pehnt, Energy Transition - The German Energiewende, Heinrich Boll Stiftung, Berlin 2014, pp. 57-59.

11. Dania rewiduje politykę klimatyczną. Promocja OZE była zbyt droga [Denmarkrevises its climate policy. The promotion of RES proved to be too expensive], http://www.cire.pl/item,130388,1.html?utm_source=news letter\&utm_campaign=newsletter\&utm_medium $=$ link\&a $\mathrm{pu}=32706$ [access: 10.06.2016].

12. G. Brønmo, Interconnection as a flexibility option, Energienet/dk, Berlin, 24.09.2015.

13. Electricity Regional Initiative (ERI), http://www.ceer.eu/portal/page/portal/EER_HOME/EER _ACTIVITIES/EER_INITIATIVES/ERI_ _ [access: 10.06.2016].

14. M. Ruszel, Bezpieczeństwo. Teoria i Praktyka [Sc. Theory and Pract.] 1/XXII (2016), pp. 71-72. 